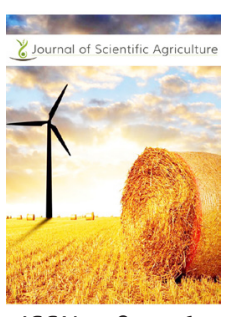

ISSN: $2184^{-0261}$
Received: July 20, 2019 Accepted: May 10, 2020 Published: May 27, 2020

Corresponding Author: Muhammad Ramzan

E-mail: ramzan.mnsua@ gmail.com

\section{Effect of different artificial diets on biological parameters of female Chrysoperla carnea under laboratory conditions}

\author{
Ghulam Murtaza', Muhammad Ramzan²*, Yaqoob Sultan³, Fahad Saleem², \\ Muhammad Arsalan Rafique ${ }^{2}$, Shahmeer Sajid², Muhammad Jamil² \\ ${ }^{1}$ Department of Entomology, University of Agriculture, Faisalabad, Pakistan, ${ }^{2}$ Institute of Plant Protection (IP²), \\ Muhammad Nawaz Shareef University of Agriculture, Multan, Pakistan, ${ }^{3}$ Department of Horticulture, Bahauddin \\ Zakariya University Multan, Punjab, Pakistan
}

\section{ABSTRACT}

Chrysoperla carnea (Neuroptera: Chrysopidae) is considered as a cosmopolitan polyphagous generalist predator Chrysoperla carnea can be used in biological control programs. The biological parameters of Chrysoperla carnea were studied to check the effect different diets under laboratory conditions. The results indicate that preoviposition, oviposition and post oviposition periods were $8.2 \pm 1.25,30.6 \pm 1.72$ and $9.4 \pm 1.02$ days, respectively. The highest mortalities were occurred reared at Water + Sugar + Yeast + Evion diets while no mortality was observed at $\mathrm{H}_{2} \mathrm{O}+$ Sugar + Yeast + Honey. The female longevity was $51.2 \pm 2.18$ days. The fecundity of female was 301.31 eggs per female with 10.36 eggs per day per single female on artificial diet, $\mathrm{H}_{2} \mathrm{O}+$ Sugar + Yeast + Honey. The study revealed that $\mathrm{H}_{2} \mathrm{O}+$ Sugar + Yeast + Honey was showed highest survival and fecundity while Water + Sugar + Yeast + Evion least one.

Keywords: Neuroptera, Artificial diet, Biological Parameters, Survival Rate, Pakistan.

\section{INTRODUCTION}

Green lacewings, Chrysoperla carnea (Stephens) belongs to the order 'Neuroptera' is an important predator of soft bodies insects. Chrysoperla carnea is found on every crop such as cotton, sweet corn, potatoes, tomatoes, peppers, okra, eggplants, leafy greens, apples, asparagus and many others where preys available. There are various biological control agents use for the management of insect pests. C. carnea is one of them, play key role in pest management. C. carnea is excessively studied due to various factors such as broad habitats with high relative frequency of occurrence, geo-graphical distribution, good searching ability and easily reared under laboratory conditions [9].

Adult is nectar, honey dew and pollen feeder while larvae of C. carnea feed on several insect pests such as aphids, thrips, spider mites, whiteflies, moths, leaf miners, small caterpillars, beetle larvae, eggs of leafhoppers and the tobacco budworm etc. $[1,5,8,10,16,17,22]$. The oval shape eggs are laid singly at the end of long silken stalks. The colour of eggs are pale green and turn gray before hatching. The larvae are very active with well-developed legs and gray or brownish in colour[13]. Adult of green lacewings are pale green, about $12-20 \mathrm{~mm}$ long, with long antennae andbright, golden eyes. They have large, transparent, pale green wings and a delicate body.During evening and night, adults are active fliers and havefluttering flight $[14,26]$. There are several generations of C. carnea annually [23, 27].

The rearing of C. carnea on different artificial diets is the most important diagnostic means to provides a comprehensive description of the growth life cycle. Biological studies have their importance in mass raring program of natural enemies and integrated pest management (IPM)strategies. It is important to know about biological parameters such as growth, life table, variations in stages, longevity and fecundity for successful mass rearing of C. carnea in biological control program [6].Keeping in view the importance of C. carnea, the rearing of predator (C. carnea) was carried under laboratory conditions at different artificial diets.

Copyright: () The authors. This article is open access and licensed under the terms of the Creative Commons Attribution License (http://creativecommons.org/licenses/by/4.0/) which permits unrestricted, use, distribution and reproduction in any medium, or format for any purpose, even commercially provided the work is properly cited. Attribution - You must give appropriate credit, provide a link to the license, and indicate if changes were made. 


\section{MATERIALS AND METHODS}

An experimental study was conducted out from August 2018 to June-2019 on Chrysoperla carnea, using four different artificial diets as feeding substrate to investigate their effect on adults' fecundity, survival or longevity at $24 \pm 1 \mathrm{C}^{\circ}$ temperature and $30 \pm 5 \%$ relative humidity $(\mathrm{RH})$ atBiocontrol Lab Department of entomology, University of Agriculture Faisalabad.The larvae were collected from fields and brought to laboratory for rearing purpose. After emergence of adults, five days old 4 pairs of adults were kept in different transparent rearing cage (Perspex cage, Wooden cage and Glass cage) to checked the effect of four different artificial diets on egg lying capacity (Table 1). The dimensions of cage were $6 \mathrm{~cm}$ thick, $35 \mathrm{~cm}$ long, $35 \mathrm{~cm}$ high and $20 \mathrm{~cm}$ wide with $2 \mathrm{~mm}$ holes on side walls. The experiment was repeated two times for each diet. The diets which were used for C. carnea given below in Table I.

Table I: Concentration of different diets used for $C$. carnea rearing

\begin{tabular}{lll}
\hline Sr. No. & Diet & Dose \\
\hline 1 & Water + Sugar + Yeast + Honey & $4 t s p+1 t s p+2 t s p+1 t s p$ \\
2 & Water + Yeast + Honey + Egg yolk & $4 t s p+2 t s p+1 t s p+1 t s p$ \\
3 & Water + Sugar + Yeast + Evion & $4 t s p+1 t s p+2 t s p+400 m g$ \\
4 & Water + Sugar + Yeast + Egg yolk & $4 t s p+1 t s p+2 t s p+1 t s p$ \\
\hline
\end{tabular}

Note: Tsp stand for Teaspoon

Data was statistically analyzed by using SPSS and least significant difference test (LSD).

\section{Procedure for the preparation of diet}

The diet was prepared in glass jar in such a way that at first take $4 \mathrm{tsp}$ of water in a jar. Then ltsp of sugar and $2 \mathrm{tsp}$ of yeast were added, shake well to make homogenous mixture and then kept for fermentation. After 5-6 hours of fermentation period, ltsp of honey was added. Then culture was placed in a zig-zag fashion in transparent plastic strips having $2 \mathrm{~mm}$ chambers.

\section{Culture Maintenance}

1. Food provision

Two time in a day, with the help of fine camel hair brush standard adult diet was provided in droplets on paper cards.

2. Egg harvesting

Eggs were harvested black muslin cloth cover with the help of sharp razor blade.

3. Cleaning of cages

All the cages were cleaned with wet cotton wig after that dried gently with the help of tissue paper.

\section{RESULTS}

The rearing of C. carnea was carried out under laboratory conditions at different artificial diets. The adult preference was different with different diets. The study indicates that pre oviposition and oviposition period of $C$. carnea female was 5 and 45 days respectively, reared on artificial diet 1 . No mortality was occurred during pre- oviposition period while mortality occurred in post-oviposition period. The oviposition period was 45 days at which maximum oviposition occurred on $22^{\text {nd }}$ day while less or no oviposition occurred on $46^{\text {th }}$ day. In this period the first female mortality was occurred on $20^{\text {th }}$ day then $2^{\text {nd }}$ on $27^{\text {th }}$ day, $3^{\text {rd }}$ on $30^{\text {th }}$ day then on $36^{\text {th }}$ day and last mortality studied in this period was on $43^{\text {rd }}$ day. The first egg was observed at day 6 and maximum eggs (18 per female per day were observed on day 18 . The graph representing increasing and decreasing zigzag pattern. The results were given in fig. 1.

The results given in Fig. 2indicate that the pre-oviposition period of C. carnea at diet 2 was 5 days and no mortality was observed. The oviposition period was 28 days at which maximum oviposition occurred on $15^{\text {th }}$ day while less or no oviposition occurred on $28^{\text {th }}$ day. In this period the first female mortality was occurred on $10^{\text {th }}$ day then $2^{\text {nd }}$ on $13^{\text {th }}$ day, $3^{\text {rd }}$ and last mortality in this period was recorded on $20^{\text {th }}$ day. The post-oviposition period recoded on this diet was 2 days at which less mortality occurred.

The results indicate that the pre-oviposition period of C. carnea at diet 3 was 5 days having zero mortality. The oviposition period

Table 1: Egg-laying capacity of $C$. carnea in different types of cages under laboratory conditions

\begin{tabular}{lccc}
\hline Cages & \multicolumn{2}{c}{ Mean \pm S.E. } & \multirow{2}{*}{ Eggs percentage } \\
\cline { 2 - 3 } & Drifted & On substrate & \\
\hline Glass cage & $11.99 \pm 1.40^{c}$ & $270.42 \pm 20.06^{\mathrm{a}}$ & 3.90 \\
Perspex cage & $15.91 \pm 2.67^{\mathrm{b}}$ & $199.8 \pm 2.13^{\mathrm{b}}$ & 8.90 \\
Wooden cage & $40.27 \pm 3.52^{\mathrm{a}}$ & $149.99 \pm 15.89^{c}$ & 17.26 \\
\hline
\end{tabular}

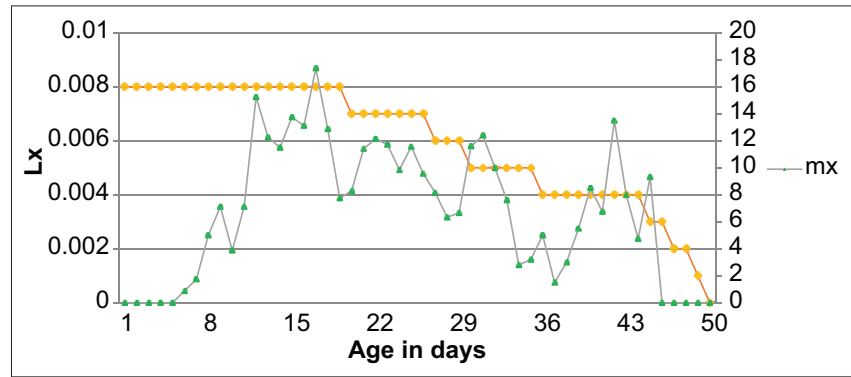

Figure 1. Age specific survival (Ix) and fecundity $(\mathrm{mx})$ of female C. carnea reared on artificial diet $\left(\mathrm{H}_{2} \mathrm{O}+\right.$ Sugar + Yeast + Honey $)$

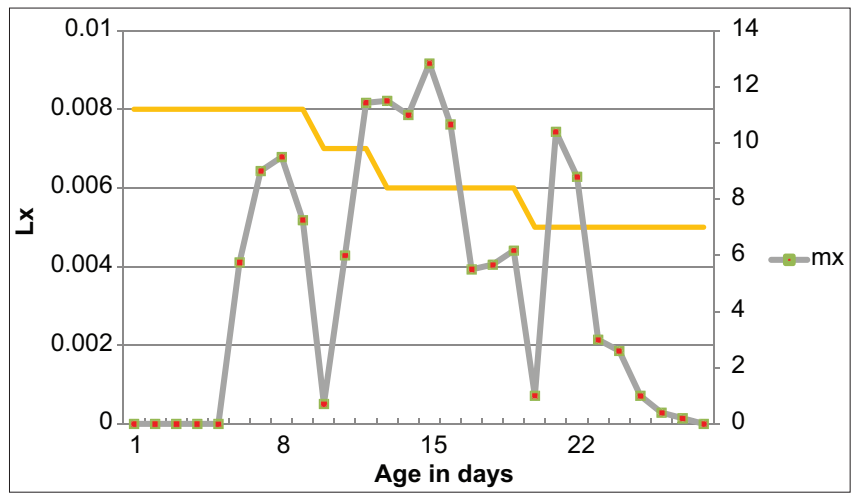

Figure 2. Age specific survival (Ix) and fecundity $(\mathrm{mx})$ of female C. carnea reared on artificial diet (Water+Yeast+Egg yolk+ Honey) 
was 32 days at which maximum oviposition occurred on $17^{\text {th }}$ day while less or no oviposition occurred on $35^{\text {th }}$ day. In this period the first and second female mortality was occurred on $22^{\text {th }}$ day then $3^{\text {td }}$ on $29^{\text {th }}$ day, $4^{\text {th }}$ on $30^{\text {th }}$ day $5^{\text {th }}, 6^{\text {th }}$ and $38^{\text {th }}$ day then $7^{\text {th }}$ and last mortality in this period was recorded on $40^{\text {th }}$ day. The postoviposition period recoded on this diet was 3 days with highest mortalities. In the mentioned graph the oviposition period was $38^{\text {th }}$ to $40^{\text {th }}$ days and hence their life cycle was completed (Fig. 3).

The results indicate that the pre-oviposition period of C. carnea at diet 4 was 5 days having zero mortality. The oviposition period was 16 days at which maximum oviposition occurred on $19^{\text {th }}$ day while less or no oviposition occurred on $15^{\text {th }}$ day. In this period the first female mortality was occurred on $11^{\text {th }}$ day then second on $15^{\text {th }}$ day while $3^{\text {rd }}$ and last mortality in this period was recorded on $22^{\text {th }}$ day (Fig. 4). The post-oviposition period recoded on this diet was 5 days at which maximum mortality occurred. The glass cages proved to be a better substrate for egg-laying of C. carnea.

The diet 1 such as $\mathrm{H}_{2} \mathrm{O}+$ sugar + yeast + Honey was the maximum preference of C. carnea while Evion $400 \mathrm{mg}$ (Vitamin E) least one. The adults fed readily on the diet and appeared to use the same type of feeding behavior or activity that they fed on natural diet. The capacity of egg lying was the same as in the natural diet. The effect of artificial diet on different stages was given in Table 2 .

Table followed by same letter in a column are not significantly different from each other $(\mathrm{P}>0.05 \%)$.

\section{DISCUSSION}

Biological control is the part of integrated pest management strategy and play key role in pest population management [15].

Table 2: Impact of artificial larval diet on Chrysoperla carnea

\begin{tabular}{lcccc}
\hline Diet & Larval survival & Pupation & Emergence & Fecundity \\
\hline 1. & $89.75^{\mathrm{a}}$ & $87.77^{\mathrm{a}}$ & $71.65^{\mathrm{a}}$ & $301.31^{\mathrm{a}}$ \\
2. & $64.00^{\mathrm{b}}$ & $50.36^{\mathrm{b}}$ & $25.99^{\mathrm{b}}$ & $105.70^{\mathrm{b}}$ \\
3. & $32.00^{\mathrm{c}}$ & $23.09^{\mathrm{c}}$ & $14.69^{\mathrm{c}}$ & $51.67^{\mathrm{c}}$ \\
4. & $17.75^{\mathrm{a}}$ & $21.77^{\mathrm{a}}$ & $20.65^{\mathrm{a}}$ & $219.31^{\mathrm{a}}$ \\
LSD & 10.104 & 19.20 & 10.901 & 29.24 \\
$=0.050$ & & & & \\
\hline
\end{tabular}

By using LSD test, means are not significantly different from each other $(P>0.05)$.

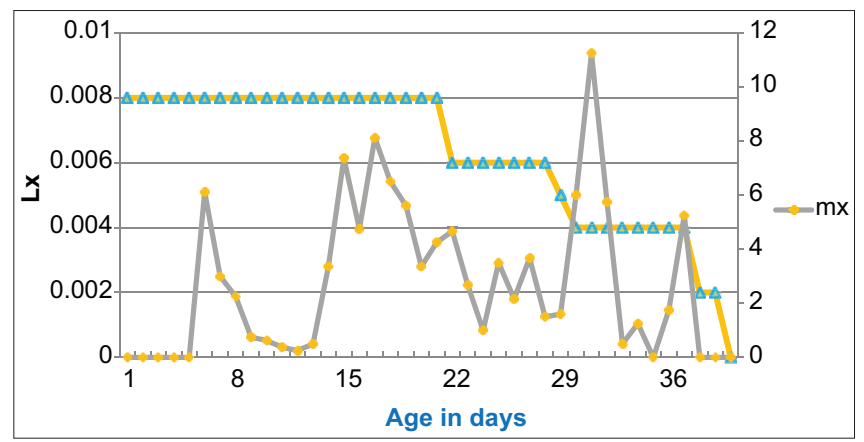

Figure 3. Age specific survival $(\mathrm{Ix})$ and fecundity $(\mathrm{mx})$ of female C. carnea reared on artificial diet (Water+Sugar+Yeast+Evion)
Green lacewings, Chrysoperla carnea (Stephens) larvae are important predators of soft bodies insect pests such as aphid, mites and whitefly. An experimental study was conducted to reared the adult of $C$. carnea by using different artificial diets because this insect is useful as a predator of sucking pests [3]. Many chewing insect pests such as Heliothis species can be controlled by inundative releases of $\mathrm{C}$. carnea eggs and larvae on cotton crop [21]. Many studies have been carried out on the rearing of $C$. carnea larvae on artificial as well as natural diets. The fecundity, longevity, reproductive age and many other reproductive as well as biological parameters of C. carnea have been examined on different diets[2].

Among all used artificial diet standards checked, diet No.l showed good results for successful commercial based mass rearing of green lacewings (Fig. 1). During the study the highest survival, fecundity was showedand no mortality occurred on diet 1 , followed by diets 2, 3 and 4. The similar findings was observed by earlier researchers [20]. Highest larval survival was observed (89.75) on diet No.1, followed by (64.00) on diet No. 2. Maximum pupation (87.77) showed in diet No. 1, while minimum (21.77) in diet No.4. Emergence was the highest (71.65) in diet No.1, followed by (25.99) in diet No.2, and the lowest (14.69) in diet-No. 3. The present study outcomes are similar with the earlier studies[20]. The predacious insects such as C. carnea feed well on the artificial diet as compared to natural prey [4]. The length of larval period was also affected with artificial diets.

During the study, it was observed that artificial diets effect the oviposition, post-oviposition periods and fecundity. The pre-oviposition and longevity periods were not influence through artificial diets [20]. The oviposition period ranged from 5.24 to 29.14 eggs/day when fed with different adult food supplements. Another study was carried out on Coccinella septempunctata at artificial diet under laboratory conditions [26]. The findings of the study were similar with the findings of current study.

Another study was carried in Pakistan resulted that pre oviposition, oviposition and post oviposition periods were $9.2 \pm 1.25,34.6 \pm 1.72$ and $7.4 \pm 1.02$ days, respectively. Our findings were contrast with the earlier findings [11], reported a single female laid $11.16 \pm 1.31$ eggs per day per.

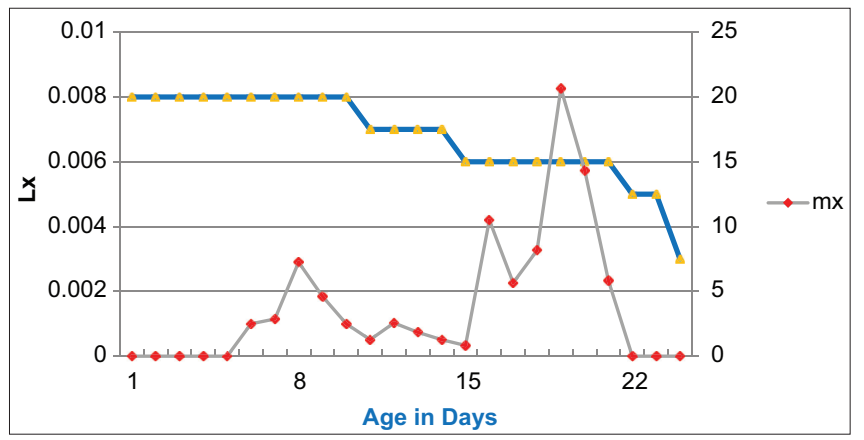

Figure 4. Age specific survival (Ix) and fecundity $(\mathrm{mx})$ of female C. carnea reared on artificial diet (Water+Sugar+Yeast+Egg yolk) 
The similar observations have been reported by many workers [7, 12, 18, 19, 24]. The variations in results can occurred due to environmental conditions such as temperature, humidity and rainfall as reported by many researchers.

The findings of the present study about biological parameters of C. Carnea were suggested the use of predator as biological control agent in IPM strategies.Due to the greater searching and egg lying capacity to hosts, higher net reproductive rate, faster development, predator use as a biological agent in pests management.

\section{CONCLUSION}

Finding of present research conclude that among the tested different artificial diets standard diet is most suitable and effective for the biological parameters of female adults and further.

\section{List of Abbreviations}

IPM: Integrated pest management

LSD: Least significant difference

SPSS: Statistical Package for the Social Sciences

Tsp: Teaspoon.

\section{CONFLICT OF INTEREST}

Authors have no conflict of interest.

\section{AUTHORS CONTRIBUTIONS}

MR wrote the manuscript, GM conducted the study, FS, MAR, $\mathrm{SS}$ and $\mathrm{MJ}$ reviewed the manuscript.

\section{ACKNOWLEDGEMENT}

Writer is highly thankful to University of Agriculture, Faisalabad and Muhammad Nawaz Shareef University to perform this study and providing favorable environment for manuscript writeup.

\section{Significant Statement}

The current study has very significance for entomologist and farmers because it provides well information about insect pest management through biological agents under changing climatic system.

\section{REFERENCES}

1. Adane T, Gautam RD, Tesfaye A. Biology and feeding potential of green lacewing Chrysoperla carnea oh non-rice moth prey. Indian Journal of Entomology, 2001; 64: 457-464.

2. Adane T, Gautam RD, Tesfaye A. Effect of adult food supplements on reproductive attributes and longevity of Chrysoperla carnea Stephens (Neuroptera: Chrysopidae). Annls of Plant Protection Science, 2002;
10: 198-201.

3. Bellows TS. Restoring population balance through natural enemy introduction. Biological Control, 2001; 21: 199-205

4. Cohen AC. Using a systematic approach to develop artificial diets for predators; In: Advances in insect rearing for research and pest management (eds. T. Anderson and N. C. Leppla), Westview Press, Oxford, 1992; 77-92.

5. El-Serafi HAK, Abdel-Salam AH, Abdel-Baky NF. Effect of four aphid species on certain biological characteristics and life table parameters of Chrysoperla carnea (Stephen) and Chrysopa septempunctata (Wesmael) (Neuroptera: Chrysopidae) under laboratory condition. Pakistan Journal of Biological Sciences, 2000; 3, 239-245.

6. Gabre RM, Adham FK, Chi H. Life table of Chrysomyamegacephala (Fabricius) (Diptera: Calliphoridae) Journal Acta Oecologica, 2005: 27:179-183

7. Geethalakshmi L, Muthukrishnan N, Chandrasekaran M, Raghuraman M. Chrysopids biology on Corcyra cephalonica and feeding potential on different host insects. Annals of Plant Protection Sciences, 2000; 8: 132-135.

8. Grenier S, Greany PD, Cohen AC. Potential for mass release of insect parasitoids and predators through development of artificial culture techniques. In: Pest Management in the Subtropics: Biological Control A Florida Perspective (D. Ronen, F. D. Bennett, and J. L. Capinera, Eds.), 1994; 181-206

9. Hoddle MS, Robinson L. Evaluation of factors influencing augmentative releases of Chrysoperla carnea for control of Scirtothrips perseae in California avocado orchards. Biological Control, 2004; 31:268-275

10. Jagadish KS, Jayaramaiah M. Biology and predatory potentiality of Chrysoperla carnea (Neuroptera) on the tobacco aphid, Myzus nicotianae (Homoptera). Journal ofEcobiology, 2004; 16: 161-167.

11. Khan J, Ehsan-ul-Haq H, Javed I, Mahmood T, Rasool A, Akhtar N, Abid S. Biological parameters and predatory potential of Chrysoperla carnea (Neuroptera: Chrysopidae) feeding on wheat aphid Schizaphis graminum (Hemiptera: Aphididae) under laboratory conditions. Pakistan Journal of Agricultural Research, 2013; 26(4).

12. Mannan VD, Varma GC, Barar KS. Biology of Chrysoperla carnea (Stephens) on Aphis gossypii (Glover) and Myuzs persicae (Sulzer). Journal of Insect Sciences, 1997; 10: 143-145.

13. Medina P, Budia F, Del Estal P, Vinuela E. Influence of Azadirachtin, a botanical insecticide, on Chrysoperla carnea (Stephens) reproduction: toxicity and ultrastructural approach. Journal of Economic Entomology, 2004; 97: 43-50.

14. Mendel Z, Dunkelblum E, Branco M, Franco JC, Kurosawa S, Mori K Synthesis and structure-activity relationship of diene modified analogs of Matsucoccus sex pheromones. Naturwissenschaften, 2003; 90: 313-317.

15. Olkowski W, Dietrick E, Lkowski H. The biological control industry in the United States, Part-II. IPM Practitioner, 1992; 14: 12-14.

16. Pappas ML, Broufas GD, Koveos DS. Effects of various prey species on development, survival and reproduction of the predatory lacewing Dichochry saprasina (Neuroptera: Chrysopidae). Journal of Biological Control, 2007; 43: 163- 170

17. Ragsdale DW, Landis DA, Jacques B, Heimpel GE, Desneux N Ecology and management of the soybean aphid in North America. Annual Review of Entomology, 2011; 56: 375-379.

18. Saminathan VR, Mahadevan NR, Muthukrishnan N. Influence of prey density on the predatory potential and development of Chrysoperla carnea. Indian Jou rnal of Entomology, 2003; 65: 1-6.

19. Saminathan VS, Muralibaskaran RK, Mahadevan NR. Biology and predatory potential of green lacewing Chrysoperla carnea (Steph.) (Neuroptera: Chrysopidae) on different insect hosts. Indian Journal of Agriculture Sciences, 1999; 69: 502-505.

20. Sattar MUZAMMIL, Fatima B, Ahmed NAZIR, Abro GH. Development of Larval Artificial Diet of Chtysoperla carnea (Stephens) (Neuroptera: Chrysopidae). Pakistan Journal of Zoology, 2007; 39: 103.

21. Sengonea C, Henze M. Conservation and enhancement of Chrysoperla carnea (Stephens) (Neuroptera: Chrysopidae) in the field by providing hibernation shelters. Journal of applied Entomology, 1992; 114: 497-501.

22. Tauber MJ, Tauber CA, Daane KM, Hagen KS. Commercialization of predators: recent lessons from green lacewings (Neuroptera: Chrysopidae: Chrysoperla). American Entomologist, 2000; 46: 26-38.

23. Tauber MJ, Tauber CA, Lopez-Arroyo, JI. Life-history variation in 
Murtaza, et al.

Chrysoperl acarnea: Implications for rearing and storage a Mexicon population. Biological Control, 1997a; 8: 185-190.

24. Tesfaye A, Gautam RD. Effect of adult food supplements on reproductive attributes and longevity of Chrysoperla carnea Stephens (Neuroptera: Chrysopidae). Annal. Plant Protection Science, 2002; 10:198-201.

25. Zhang F, Wang S, Luo C, Chen Y, Li F. Effects of artificial diet and breeding methods on growth and development of Chryopa septempunctata. Plant Protection science, 2004; 30:36-40.

26. Zhang QH, Sheng ML, Chen GF, Aldrich JR, Chauhan KR. Iridodial: A powerful attractant for the green lacewing, Chryopa septempunctata (Neuroptera: Chrysopidae). Naturwissenschaften, 2006; 93:461-465.

27. Zhu JW, Obrycki JJ, Ochieng SA, Baker TC, Pickett JA, Smiley D. Attraction of two lacewing species to volatiles produced by host plants and aphid prey. Naturwissenschaften, 2005; 92:277-281. 